\title{
Sub-State Actors and Searching for Alternatives to the State-Centric's International System
}

\author{
Inass Abdulsada Ali \\ Assistant Professor of International Studies, University of Baghdad, College \\ of Political Science, Dep. of International Studies, Baghdad, Iraq
}

\begin{abstract}
The multiplicity of actors requires the state adapts itself according to the changes and developments that occur in the international system and the world order. The sub-state play an effective external political role that serves the process of reaching the economic and political goals of the state. The sub-state does not change the regional map of the state. As a result, the state's sovereignty remains extended to this map, even if the function changed. The state can employ the reality of double loyalties and overlapping realms of power inside to push the effects that non-states actors pose. The state gives way to the partnership in the global order in terms of creating values and norms of behavior, but it remains dominant over the international system with no partner.
\end{abstract}

Keywords: Sub-State; Sovereign State; International System; World Order; Westphalian State-Centric System. 